\title{
PERAWATAN PALIATIF DAN KUALITAS HIDUP PENDERITA KANKER
}

\author{
Anita \\ Jurusan Keperawatan, Politeknik Kesehatan Tanjungkarang \\ Email: anitabustami@yahoo.co.id
}

\begin{abstract}
Palliative Care and Quality of Life Patients. Riskesdas in 2013, the prevalence of cancer in Indonesia is 1.4 per 1000 population, or about 330,000 people. Cancer is the leading cause of death No. 7 in Indonesia. Patients in the highest cancer is breast cancer and cervical cancer (Ministry of Health, Mediakom, 55th edition, 2015). The treatment of cancer has a negative impact on the physical and mental, as well as having considerable influence on the self-concept. If the self-concept is compromised, then the effect on the mind and behavior, among other things: sadness, anxiety and fear of the future and death. This condition affects the quality of life of cancer patients. Quality of life of cancer patients affected individual's understanding of the disease, so that patients know how to maintain health. Dimensional aspects that affect the quality of life of patients are physical, psychological, social relationships and environment. Through palliative care patients reluctant to be more able to accept the situation so that they can live their lives despite its age soon. The quality of life of patients with incurable diseases will continue to deteriorate or fall if the expectations of patients do not correspond with the reality. Palliative care provides support in terms of spiritual and psycho-social, moral support to the bereaved family. That requires empathy and a special ability to perform palliative care from health professionals. One important aspect of palliative care is love, caring, sincerity and gratitude. Once the importance of this aspect, to exceed the absolute importance of pain management should be done in palliative care. Palliative care is a companion medical treatment. Palliative care is an important part in the treatment of cancer patients with the highest priority is quality of life rather than cure the patient. Increasing the quality of life of patients for palliative care, is expected to help the patient ready psychologically and spiritually, and no stress of dealing with her illness.
\end{abstract}

Keywords: Palliative Care, Quality of life, Cancer

\begin{abstract}
Abstrak: Perawatan Paliatif dan Kualitas Hidup Penderita. Data riskesdas tahun 2013 prevalensi kanker di Indonesia adalah 1,4 per 1000 penduduk atau sekitar 330.000 orang. Kanker merupakan penyebab kematian no 7 di Indonesia. Penderita kanker tertinggi di adalah kanker payudara dan kanker leher rahim (Kemenkes, Mediakom, edisi 55, 2015). Pengobatan kanker memberi dampak negatif pada fisik dan mental, serta mempunyai pengaruh yang besar terhadap konsep diri. Jika konsep diri terganggu, maka berpengaruh terhadap pikiran dan tingkah laku seseorang, antara lain: kesedihan, kekhawatiran dan ketakutan akan masa depan dan kematian. Kondisi ini mempengaruhi kualitas hidup penderita kanker. Kualitas hidup penderita kanker dipengaruhi pemahaman individu terhadap penyakitnya, sehingga penderita tahu cara menjaga kesehatan. Aspek dimensi yang mempengaruhi kualitas hidup penderita adalah fisik, psikologis, hubungan social dan lingkungan. Melalui perawatan paliatif penderita diajak untuk lebih bisa menerima keadaannya sehingga masih bisa menjalani hidupnya meskipun umurnya tak lama lagi. Kualitas hidup penderita dengan penyakit tak bisa disembuhkan akan terus memburuk atau menurun jika harapan penderita tidak sesuai dengan kenyataan yang ada. Perawatan paliatif memberikan dukungan dalam hal spiritual dan psikososial, dukungan moral kepada keluarga yang berduka. Untuk itu dibutuhkan empati yang besar dan kemampuan khusus dalam melakukan perawatan paliatif dari tenaga kesehatan. Salah satu aspek penting dalam perawatan paliatif adalah kasih, kepedulian, ketulusan, dan rasa syukur. Begitu pentingnya aspek ini, sampai melebihi pentingnya penanganan nyeri yang mutlak harus dilakukan dalam perawatan paliatif. Perawatan paliatif merupakan pendamping pengobatan medis. Perawatan paliatif merupakan bagian penting dalam perawatan penderita kanker dengan prioritas utama adalah kualitas hidup dan bukan kesembuhan penderita. Meningkatnya kualitas hidup penderita karena perawatan paliatif, diharapkan akan membantu penderita siap secara psikologis dan spiritual, serta tidak stres menghadapi penyakit yang dideritanya.
\end{abstract}

Kata kunci: Perawatan Paliatif, Kualitas hidup, Kanker 

World Health Organization (WHO) 2013 menyatakan kanker menjadi penyebab kematian nomor dua di dunia sebesar $13 \%$ setelah penyakit kardiovaskuler. Diperkirakan tahun 2030 insidens kanker mencapai 26 juta orang dan 17 juta diantaranya meninggal akibat kanker (Kemenkes, Mediakom, edisi 5), 2015). Di Indonesia berdasarkan data riskesdas tahun 2013 prevalensi tumor/ kanker di Indonesia adalah 1,4 per 1000 penduduk atau sekitar 330.000 orang.

Kanker merupakan penyebab kematian no 7 di Indonesia. Penderita kanker tertinggi di Indonesia adalah kanker payudara dan kanker leher rahim (Kemenkes, Mediakom, edisi 5). Berdasarkan sistem informasi RS (SIRS). Jumlah penderita rawat jalan maupun rawat inap pada kanker payudara terbanyak yaitu 12014 orang $(28,7 \%)$ dan kanker serviks 5,349 orang $(12,8 \%)$.

Kanker memiliki berbagai macam jenis dengan berbagai akibat yang timbul. Ancaman kematian dan penurunan kualitas hidup membayangi jutaan penderita kanker. Menurut Persatuan Ahli Bedah Onkologi Indonesia (2005) yang dikutip oleh Lutfa (2008), penatalaksanaan/ pengobatan utama penyakit kanker meliputi pembedahan, radioterapi, kemoterapi dan hormonterapi. Pembedahan dilakukan untuk mengambil massa kanker dan memperbaiki komplikasi yang mungkin terjadi. Tindakan radioterapi dilakukan dengan sinar ionisasi untuk menghancurkan kanker. Kemoterapi dilakukan untuk membunuh sel kanker dengan obat antikanker (sitostatika). Sedangkan hormonterapi dilakukan untuk mengubah lingkungan hidup kanker sehingga pertumbuhan sel-selnya terganggu dan akhirnya mati sendiri. Keberhasilan pengobatan ini tergantung dari ketentuan penderita dalam berobat dan tergantung pada stadiumnya.

Pengobatan kanker memberi dampak negatif pada fisik maupun mental dan mempunyai pengaruh yang besar terhadap konsep diri. Konsep diri akan mempengaruhi pikiran dan tingkah laku seseorang. Mengalami kebotakan dan dan kecacatan, akan membuat penderita merasa tubuhnya tidak menarik lagi, sehingga hubungan interpersonal juga menjadi tidak harmonis. Kondisi penderita kanker stadium lanjut tidak dapat kembali ke keadaan semula, dikarenakan gangguan konsep diri yang terjadi dalam dirinya yakni kecacatan tubuh dan penurunan fungsi organ tubuh (Lubis, 2009).

Penelitian yang dilakukan oleh Saraswati (2009) di Ruang Rawat Inap RSUP Dr. Kariadi Semarang dengan menggunakan 30 orang penderita kanker yang telah mendapat kemoterapi, hasil penelitiannya menunjukkan bahwa sebagian besar konsep diri responden yang menghadapi kemoterapi tergolong sedang yaitu sebesar (87\%), konsep diri responden tergolong tinggi (13\%) sedangkan proporsi terkecil yang mendapat kemoterapi adalah konsep diri yang tergolong rendah yaitu $(0 \%)$. Dapat disimpulkan bahwa konsep diri penderita kanker yang mendapat kemoterapi di Ruang Rawat Inap RSUP Dr. Kariadi Semarang tergolong sedang.

Penelitian yang dilakukan oleh Lutfa (2008) pada awal bulan Oktober 2007 dengan melakukan wawancara terhadap penderita kanker yang menjalani kemoterapi di ruang Cendana 1 RSUD Dr. Moewardi sebanyak 34 responden, hasil penelitiannya menunjukkan bahwa sebagian besar penderita rambutnya menjadi rontok, merasa mual dan muntah, $25 \%$ penderita merasakan perannya sangat berkurang. Penderita laki-laki merasa tidak mampu lagi menghidupi keluarga, tidak mampu berdekatan dengan anak dan mengurusnya.

Beberapa penelitian yang dilakukan hanya melihat hubungan antara faktor risiko dengan terjadinya kanker, tanpa memperhatikan bagaimana perawatan penderita kanker yang tidak memberikan reaksi positif terhadap pengobatan. Penderita kanker pada umumnya memerlukan perawatan paliatif dalam menghadapi penyakit yang diderita. Kualitas hidup penderita sangat diperlukan ditengah keputus asaan memperoleh kesembuhan penyakit.

Perawatan penderita kanker yang menjalani kemoterapi hanya memberikan perawatan rutin seperti penderita sakit pada umumnya. Pengelolaan penderita lebih banyak berfokus pada kondisi sakit fisik, dan belum secara holistik integratif. Perawatan paliatif belum mendapat perhatian khusus dalam memberikan asuhan keperawatan, masing-masing tenaga kesehatan hanya memberikan pelayanan terhadap kebutuhan fisik yang dirasakan penderita. Berdasarkan data WHO, terdapat lebih dari 40 juta orang di dunia yang membutuhkan perawatan paliatif, namun hanya 14 persen saja yang baru memperolah perawatan tersebut. Sama halnya di Indonesia, masih banyak masyarakat yang belum mengetahui perwatan paliatif itu sangat penting dalam upaya peningkatan kualitas hidup penderita. Berdasarkan uraian di atas penting diketahui bagaimanakah perawatan paliatif dapat meningkatkan kualitas hidup penderita kanker. 


\section{PERAWATAN PALIATIF}

Pelayanan paliatif pasien kanker adalah pelayanan terintegrasi oleh tim paliatif untuk meningkatkan kualitas hidup pasien dan memberikan dukungan bagi keluarga yang menghadapi masalah yang berhubungan dengan kondisi pasien dengan mencegah dan mengurangi penderitaan melalui identifikasi dini, penilaian yang seksama serta pengobatan nyeri dan masalah-masalah lain, baik masalah fisik, psikososial dan spiritual (WHO, 2002) dan pelayanan masa dukacita bagi keluarga (WHO, 2005) dalam Pedoman teknis pelayanan paliatif kanker, 2013). Perawatan paliatif adalah perawatan kesehatan terpadu yang bersifat aktif dan menyeluruh, dengan pendekatan multidisiplin yang terintegrasi.

Tujuan perawatan paliatif adalah untuk mengurangi penderitaan, memperpanjang umur, meningkatkan kualitas hidup, dan memberikan support kepada keluarga penderita. Meski pada akhirnya penderita meninggal, yang terpenting sebelum meninggal penderita siap secara psikologis dan spiritual, serta tidak stres menghadapi penyakit yang dideritanya.

Perawatan paliatif diberikan sejak diagnosa ditegakkan sampai akhir hayat. Artinya tidak memperdulikan pada stadium dini atau lanjut, masih bisa disembuhkan atau tidak, mutlak perawatan paliatif harus diberikan kepada penderita. Perawatan paliatif tidak berhenti setelah penderita meninggal, tetapi masih diteruskan dengan memberikan dukungan kepada anggota keluarga yang berduka.

Perawatan paliatif mencakup pelayanan terintegrasi antara dokter, perawat, pekerja social, psikolog, konselor spiritual, relawan, apoteker dan profesi lain yang diperlukan.

Kemenkes (2013), menjelaskan prinsip pelayanan paliatif pasien kanker: 1) menghilangkan nyeri dan gejala fisik lain, 2) menghargai kehidupan dan menganggap kematian sebagai proses normal, 3) tidak bertujuan mempercepat atau menunda kematian, 4) mengintegrasikan aspek psikologis, social dan spiritual, 5) memberikan dukungan agar pasien dapat hidup seaktif mungkin, 6) memberikan dukungan kepada keluarga sampai masa dukacita, 7) menggunakaan pendekatan tim untuk mengatasi kebutuhan pasien dan keluarganya, 8) menghindari tindakan sia-sia.

Perawatan paliatif berupaya meringankan penderitaan penderita yang sudah sakit parah dan tidak dapat disembuhkan seperti misalnya kanker stadium akhir, penderita penyakit motor neuron, penyakit degeneratif saraf dan penderita
HIV/AIDS. Pada akhirnya penderita diharapkan dapat menjalani hari-hari sakitnya dengan semangat dan tidak putus asa serta memberi dukungan agar mampu melakukan hal-hal yang masih bisa dilakukan dan bermanfaat bagi spiritual penderita.

Perawatan paliatif lebih berfokus pada dukungan dan motivasi ke penderita. Kemudian setiap keluhan yang timbul ditangani dengan pemberian obat untuk mengurangi rasa sakit. Perawatan paliatif ini bisa mengeksplorasi individu penderita dan keluarganya bagaimana memberikan perhatian khusus terhadap penderita, penanggulangannya serta kesiapan untuk menghadapi kematian.

Perawatan paliatif dititikberatkan pada pengendalian gejala dan keluhan, serta bukan terhadap penyakit utamanya karena penyakit utamanya tidak dapat disembuhkan. Dengan begitu penderita terbebas dari penderitaan akibat keluhan dan bisa menjalani akhir hidupnya dengan nyaman.

Perawatan paliatif diperlukan karena: Setiap orang berhak dirawat dan mati secara bermartabat, menghilangkan nyeri: fisik, emosional, spiritual dan sosial adalah hak asasi manusia, perawatan paliatif adalah kebutuhan mendesak seluruh dunia untuk orang yang hidup dengan kanker stadium lanjut.

Berbagai hal terkait pendekatan keperawatan paliatif yang perlu mendapatkan perhatian diantaranya adalah: 1) komunikasi antar tim, 2) manajemen nyeri, 3) bimbingan dan pertimbangan budaya dalam pengambilan keputusan, dan 4) dukungan emosional dan spiritual bagi paisen dan keluarga.

\section{SEPERTI APA PERAWATAN PALIATIF ITU?}

Intinya perawatan ini lebih berupa dukungan dan motivasi ke penderita. Perawatan paliatif bisa mengeksplorasi individu penderita dan keluarganya bagaimana memberikan perhatian khusus terhadap penderita, penanggulangannya serta kesiapan untuk menghadapi kematian.

Langkah-langkah dalam pelayanan paliatif (Kemenkes, 2013),adalah:

1. Menentukan tujuan perawatan dan harapan pasien

2. Memahami pasien dalam membuat wasiat atau keinginan terakhir

3. Pengobatan penyakit penyerta dan aspek social

4. Tatalaksana gejala 
5. Informasi dan edukasi

6. Dukungan psikologis, cultural dan social

7. Respon fase terminal

8. Pelayanan pasien fase terminal

Aktifitas perawatan paliatif pada penderita:

1. Membantu penderita mendapat kekuatan dan rasa damai dalam menjalani kehidupan sehari-hari.

2. Membantu kemampuan penderita untuk mentolerir penatalaksanaan medis.

3. Membantu penderita untuk lebih memahami perawatan yang dipilih.

Aktifitas perawatan paliatif pada keluarga:

1. Membantu keluarga memahami pilihan perawatan yang tersedia.

2. Meningkatkan kehidupan sehari-hari penderita, mengurangi kekhawatiran dari orang yang dicintai (asuhan keperawatan keluarga).

3. Memberi kesempatan sistem pendukung yang berharga.

Pelayanan asuhan keperawatan penderita meliputi pemenuhan kebersihan diri (mandi, berhias, kebersihan mulut, perawatan kuku), kebutuhan nutrisi, kebutuhan tidur dan kenyamanan tempat tidur dan memfasilitasi lingkungan ruang rawat yang kondusif. Kebutuhan saat-saat terminal adalah memberi dukungan pada keluarga (memberikan kesempatan bertanya, memberikan informasi, memberikan saran cara memberikan dukungan pada penderita, menyediakan barang-barang yang memberi rasa nyaman, menyediakan dukungan interdisiplin).

Selain mengurangi gejala-gejala yang muncul, perawatan paliatif juga memberikan dukungan dalam hal spiritual dan psikososial. Perawatan paliatif setelah penderita meninggal dilakukan dengan memberikan dukungan moral kepada keluarga yang berduka. Bagi tenaga kesehatan dibutuhkan empati yang besar dan kemampuan khusus dalam melakukan perawatan paliatif. Salah satu aspek penting dalam perawatan paliatif adalah kasih, kepedulian, ketulusan, dan rasa syukur. Begitu pentingnya aspek ini, sampai melebihi pentingnya penanganan nyeri yang mutlak harus dilakukan dalam perawatan paliatif.

Tim perawatan paliatif harus berupaya untuk membuat penderita menerima keadaannya sehingga masih bisa menjalani hidupnya meskipun umurnya tak lama lagi. Kebanyakan kualitas hidup penderita dengan penyakit tak bisa disembuhkan akan terus memburuk atau menurun, jika harapan penderita tidak sesuai dengan kenyataan yang ada. Tim paliatif harus dapat memodifikasi ekspektasi penderita, sehingga jarak antara harapan dan kenyataannya menjadi lebih dekat. Bisa dengan cara membangkitkan spirit untuk hidup, orientasi masa depan, keimanan bahkan tentang seksualitasnya. Harapan selalu ada, tapi sebaiknya tidak memberikan harapan yang palsu karena harapan juga harus disesuaikan dengan hasil pemeriksaan. Untuk itu keluarga merupakan kunci makna hidup dalam perawatan paliatif.

Perawatan paliatif dapat memenuhi kebutuhan perbaikan kualitas hidup penderita dan keluarganya melalui perawatan yang tidak hanya menekankan pada gejala fisik seperti nyeri, tetapi juga terhadap aspek-aspek emosional, psikososial dan spiritual. Banyak kasus yang ditemukan ketika para penderita kanker, malu untuk bersosialisasi dan tidak percaya diri dalam menjalani kehidupannya. Kondisi seperti ini membutuhkan perawatan paliatif dalam meningkatkan kualitas hidup agar lebih baik. Selain kepada penderitanya, perawatan paliatif juga memberi dukungan kepada seluruh anggota keluarga dan pelaku rawat lainnya. (Taher, A, 2010).

Bagi penderita kanker stadium dini, perawatan paliatif merupakan pendamping pengobatan medis. Meningkatnya kualitas kehidupan penderita karena perawatan paliatif diharapkan akan membantu proses penyembuhan kanker secara keseluruhan, (Sugiaman, S, 2016).

\section{QUALITY OF LIFE}

Quality of life adalah bagaimana kualitas seseorang apabila dilihat dari interaksi dengan kehidupan di sekitarnya (Soetardjo, 2013). Konsep kualitas hidup menjadi penting untuk dibahas dalam mengevaluasi hasil akhir kualitas pelayanan kesehatan yang diberikan oleh para professional kesehatan sejalan dengan tumbuhnya kesadaran bahwa kesejahteraan penderita menjadi pertimbangan yang penting dalam memilih terapi pengobatan dan untuk mempertahankan kehidupan. Kualitas hidup menjadi pertimbangan bermakna untuk masyarakat pada umumnya, dan pelayanan kesehatan pada khususnya (http://jki.ui.ac.id/index.php/jki/article/view/236)

Penelitian Pratiwi, TF., dengan judul kualitas hidup penderita kanker, menjelaskan bahwa penyakit kanker memberikan perubahan signifikan secara fisik maupun psikis individu, antara lain: kesedihan, kekhawatiran dan ketakutan akan masa depan dan kematian. Kualitas hidup penderita kanker dipengaruhi pemahaman individu terhadap penyakitnya 
sehingga seseorang tahu cara menjaga kesehatan, serta faktor ekonomi dimana hal ini menjadi kekhawatiran khusus terhadap biaya pengobatan. Aspek dominan pembentukan kualitas hidup penderita kanker adalah aspek psikologis, meliputi spiritualitas, dukungan sosial dan kesejahteraan. Faktanya, aspek psikologis sangat menentukan kualitas hidup, penderita mendapatkan kekuatan dan merasa lebih sehat tanpa obat, hal ini disebabkan karena sugesti dalam diri individu tersebut untuk tetap sehat. Kecerdasan spiritualitas menuntun penderita memiliki penerimaan diri terhadap penyakitnya. Penderita mengalami peningkatan spiritual dibanding sebelum menderita kanker. Penderita merasa lebih dekat dengan Tuhan dan tidak menyalahkan Tuhan, melainkan menganggap sebagai sebuah anugerah Tuhan. Rasa cinta dan nyaman dari dukungan sosial memberi motivasi untuk sembuh dan kuat menjalani hidup. Akhirnya memberikan kesejahteraan yang menentukan kualitas hidup penderita.

Dibi (2015), dengan judul kualitas hidup penyandang kanker payudara, analisis terhadap data sekunder dari Asean CosTs in Oncology study yang melibatkan 785 penderita kanker payudara dari 10 rumah sakit rujukan di 8 kota besar di Indonesia. Hasil penelitian tersebut menunjukkan risiko penurunan QoL memiliki hubungan dengan tingkat pendidikan, status bekerja, pendapatan keluarga, tekanan finansial, stadium kanker, serta kondisi fungsional fisik dan kondisi fungsional psikologis penderita kanker payudara. Para penderita dengan pendidikan sekolah dasar (6 tahun) berpeluang mengalami penurunan QoL 0,6 kali lipat dibanding mereka yang berpendidikan sarjana/ sarjana muda. Artinya, para penderita berpendidikan tinggi berpeliuang mengalami risiko penurunan QoL 1,5 kali lipat dari mereka yang hanya berpendidikan SD. Sedangkan para penderita yang tidak bekerja berpeluang mengalami penurunan QoL 1,5 kali lipat dari penderita yang bekerja. Lalu para penderita dengan pendapatan keluarga yang tinggi, berpeluang mengalami penurunan QoL hampir 2 kali lipat penderita berpendapatan lebih rendah.

\section{PENGARUH PERAWATAN PALIATIF TERHADAP PERUBAHAN KUALITAS HIDUP PENDERITA KANKER}

Penelitian tentang pengaruh perawatan paliatif terhadap pasien kanker stadium akhir (literature review) yang dilakukan oleh Irawan, E, 2013, berdasarkan 30 literatur yang dianalisa, disimpulkan perubahan yang terjadi pada kanker stadium akhir menyebabkan perubahan kualitas hidup karena kualitas hidup terdiri dari empat dimensi yaitu dimensi fisik, psikologis, hubungan social dan lingkungan yang tidak hanya ditangani dengan kuratif tapi perlu pendekatan yang lebih personal pada fisik, psikologi, social dan spiritual sehingga dapat disimpulkan bahwa perawatan paliatif sangat berperan dalam tercapainya kualitas hidup maksimal pada kanker stadium IV sehingga mengurangi sakit ataupun persiapan kematian.

Berbagai masalah fisik seperti nyeri, sesak nafas, penurunan berat badan, gangguan aktifitas tetapi juga mengalami gangguan psikososial dan spiritual yang mempengaruhi kualitas hidup penderita dan keluarganya. Perawatan paliatif merupakan bagian penting dalam perawatan penderita yang terminal yang dilakukan menjadi prioritas utama adalah kualitas hidup dan bukan kesembuhan penderita.

Perawatan paliatif adalah semua tindakan aktif guna meringankan beban penderita, terutama yang tak mungkin disembuhkan. Tindakan aktif yang dimaksud adalah menghilangkan nyeri dan keluhan lain, serta mengupayakan perbaikan dalam aspek psikologis, sosial dan spiritual. Perawatan paliatif yang baik mampu merubah kualitas hidup penderita kanker seseorang menjadi lebih baik. Namun perawatan paliatif masih jarang dilakukan di rumah sakit di Indonesia, karena masih berfokus kepada kuratif, sedangkan perubahan fisik, sosial dan spiritual tidak bisa diintervensi seluruhnya dengan kuratif. Hal ini dapat dikarenakan kurangnya pemahaman dan kesadaran rumah sakit terhadap pentingnya perawatan palliatif bagi penderita kanker.

Agar kualitas hidup penderita kanker tetap tinggi, ada beberapa hal yang harus dilakukan, diantaranya adalah dengan menerapkan perawatan paliatif yang komprehensif dan terintegratif dari tim paliatif.

\section{SIMPULAN}

Perubahan pada penderita kanker menyebabkan perubahan kualitas hidup. Kualitas hidup terdiri dari dimensi fisik, psikologis, hubungan sosial dan lingkungan, keseluruhan dimensi kehidupan tidak hanya dapat ditangani secara kuratif, tetapi perlu pendekatan yang lebih personal berupa perawatan paliatif. Perawatan paliatif diberikan sejak diagnosa ditegakkan sampai akhir hayat. Perawatan paliatif tidak berhenti setelah penderita meninggal, tetapi 
masih diteruskan dengan memberikan dukungan kepada anggota keluarga yang berduka.

Perawatan paliatif mencakup pelayanan terintegrasi antara dokter, perawat, pekerja social, psikolog, konselor spiritual, relawan, apoteker dan profesi lain yang diperlukan. Perawatan paliatif adalah semua tindakan aktif guna meringankan beban penderita, terutama yang tak

\section{DAFTAR PUSTAKA}

Dibi. 2015. Kualitas Hidup Penyandang Kanker Payudara Patut Diperhatikan. http://swa.co.id/2015/07/28 (Diakses pada 5 November 2016).

Irawan, E. 2013. Pengaruh Perawatan Paliatif terhadap Pasien Kanker Stadium Akhir. ejournalbsi.ac.id/jurnal-ilmu-keperawatan. Jurnal Keperawatan. Vol 1, No.1, September 2013. Hlm 34-38.

Kemenkes RI. 2013. Pedoman Teknis Pelayanan Paliatif Kanker. Jakarta.

Kemenkes RI. 2015. Kanker Pembunuh Papan Atas. Mediakom. Edisi 55.

Lubis, N. Hasnida. 2009.Terapi Perilaku Kognitif pada Pasien Kanker. Medan: USU Press.

Lutfa, Umi. 2008. Faktor-faktor yang Mempengaruhi Tingkat Kecemasan Pasien dengan Tindakan Kemoterapi di Ruang Cendana RSUD Dr. Moewardi Surakarta. http://etd.eprints.ums.ac.id/

(Diakses tanggal 22 November 2016).

Pratiwi, TF. 2012. Kualitas Hidup penderita Kanker, Developmental and Clinical Psychology. Vol 1, No 1. mungkin disembuhkan. Tindakan aktif yang dimaksud adalah menghilangkan nyeri dan keluhan lain, serta mengupayakan perbaikan dalam aspek psikologis, sosial dan spiritual. Perawatan paliatif yang baik mampu merubah kualitas hidup penderita kanker seseorang menjadi lebih baik.

Badan Penelitian dan Pengembangan Kesehatan. 2013. Laporan Riset Kesehatan Dasar Tahun 2013. Jakarta.

Saraswati, Sri Haryani. 2009. Hubungan Antara Kecemasan pada Penderita Kanker yang Mendapat Kemoterapi dengan Konsep Diri. Jurnal Keperawatan dan Kebidanan (JIKK), Vol I, No.1 Desember 2009.

Soetarjo. 2013. Improve Your Quality of Life; Get Positive Energi and Promote Mental Health. Laporan oleh Maulana. Seminar Nasional Positif 2013 yang digelar oleh Badan Eksekutif Mahasiswa (BEM) Fapsi Unpad, Sabtu (23/02) di Aula Rumah Sakit Pendidikan Unpad, Bandung. http://www.unpad.ac.id/2013/02/kualitashidup-seseorang-terlihat-dari-interaksidengan-kehidupan-di-sekitarnya/

Sugiaman, S. 2016. Perawatan Paliatif Apa Sih?. http://i-careclinic.com/perawatan-paliatifapa-sih.html (Diakses 5 November 2016)

Taher, A. 2010. Seminar dan Konferensi Press Memperingati Hari Hospis dan Perawatan Paliatif Sedunia. Jakarta. 